\title{
The Effect of Spirituality on Turnover Intention Mediated by Employee Engagement
}

\author{
Wendell Yansens ${ }^{1}$, Melitina Tecoalu ${ }^{2 *}$, Soegeng Wahyoedi ${ }^{2}$, Fredella Colline ${ }^{2}$ \\ ${ }^{1}$ Master of Management Program, Krida Wacana Christian University, Jakarta, Indonesia \\ ${ }^{2}$ Faculty of Economics and Business, Krida Wacana Christian University, Jakarta, Indonesia \\ *Corresponding author. Email: melitina@ukrida.ac.id
}

\begin{abstract}
The objective of this study was to examine the influence of spirituality in the workplace against turnover intention mediated by employee engagement among the employees in WOM Finance Jakarta. As many as 214 employees of the head office of WOM Finance Jakarta were involved in this study. The data was obtained through a questionnaire from the respondents who were selected by using random sampling method. The Structural Equation Model (SEM) using the SmartPLS program was used for data analysis purpose. The study revealed that spirituality in the workplace does not affect the turnover intention, but spirituality in the workplace has an influence on employee engagement. Employee engagement has no influence on turnover intention, and does not mediate the influence of spirituality in the workplace against turnover intention.
\end{abstract}

Keywords: Spirituality, Employee Engagement, Turnover Intention

\section{INTRODUCTION}

WOM Finance is a multi-finance company that has been active in the financing industry in Indonesia since 1982. For approximately 37 years of runing in the Multifinance business segment, WOM Finance has more than 118 network offices throughout Indonesia and has won prestigious awards, including the Top Multifinance Awards, Top 5th Indonesia Multifinance Awards, and Indonesia Service Quality Awards. The development of the network in the territory of Indonesia requires additional human resources as a driving force for business at WOM Finance. The total number of employees working in WOM Finance until the end of 2018 was 3,658 employees. To ensure the continuity of the company's business, it is necessary to have dedicated employees who continue to work with good performance in order to generate profits for the company.

The company's ability to compete does not only come from the market for the product or service it provides, but also from the human resources it has [1]. Every company wishes to have employees who engage and continue to contribute to the company by meeting every employee's needs, paying attention to subordinates, and placing employees as part of the company's assets, not merely considering employees as workers to generate profit to the company.

Employee engagement is the enthusiasm of employees at work that occurs because they exert their energy to work, which is in line with the company's strategic priorities [2]. According to [3], if employees have enthusiasm and are totally involved with their work, they will personally work more actively, be more productive, and produce more jobs according to what customers and organizations want.

Company management needs to identify and evaluate the level of employee engagement in the institution with a belief that the engaged employees will have a high level of commitment and greater loyalty to the institution [4]. One of the efforts of company management to increase the involvement and enthusiasm of employees towards organizational goals, is to use a spiritual approach that is integrated into the organizational values, corporate culture, and work environment.

[5] mentioned that spirituality can increase employee engagement. Spirituality is the most invisible part of human beings and gives meaning and purpose to life and attachment to God Almighty. According to [6], spirituality is the awareness that human beings have as an inner life that grows and is cultivated by meaningful work and takes place in a community context. Employee turnover also occurs at WOM Finance with a fairly high percentage.

Table 1 Turnover Rate 2016-2018

\begin{tabular}{|c|c|c|c|}
\hline Year & Employees Enter & Employees Leave & Percentage of Employees Leaving \\
\hline 2016 & 218 & 76 & $35 \%$ \\
\hline 2017 & 268 & 97 & $36 \%$ \\
\hline 2018 & 453 & 194 & $43 \%$ \\
\hline
\end{tabular}

Source: WOM Finance (2018) 
Based on the explanation above, the researcher aimed to examine: 1) whether spirituality affects turnover intention; 2) whether spirituality affects employee engagement, 3) whether employee engagement affects turnover intention; and 4) whether spirituality affects turnover intention mediated by employee engagement.

\section{LITERATURE REVIEW}

\subsection{Spirituality}

Spirituality awakens people to have an inner life that is growing and is fostered by the work that takes place in the community context [6]. Organizations that support spiritual culture recognize that people have their minds and souls, that seek the meaning and purpose in their work, and the desire to relate to other people in order to be part of a community. The study of spirituality was inspired by [7] regarding the idea of the importance of the meaning of life in the world of work. Spirituality is a new concept in management models and organizational behavior, especially organizational culture. The terms commonly used are workplace spirituality, spirituality in the workplace, spirituality at work, spiritual workplace, or spirit at work. Spirituality has actually been described in the concept of organizational behaviour such as values and ethics. [6] explained that "the concept of workplace spirituality draws on our previous discussion of topics as values, ethics, leadership, work/life balance, and motivation". [5] stated that spirituality is the most important part of human beings which cannot be seen and provides meaning and purpose in life and attachment to God Almighty. He also emphasized that spirituality is different from religion, in which religion is part of the spirituality itself. This is supported by [8] who stated from a religious and psychological perspective, that spirituality is central and has an essentially religious function. Meanwhile, in the context of work, spirituality was stated by [9], in which employees understand themselves as spiritual beings.

\subsection{Employee Engagement}

In every institution, work engagement is very important, because it can provide motivation to achieve high performance. [10] defined engagement as something positive, fully fulfilling the employees' needs, positive work related to high morale and mental resilience at work, is very involved in work that is done with full concentration, and is very dedicated to workers.

[11] stated that employee engagement is an effort by organizational members to bind themselves to their job roles. In this condition, people will engage and express themselves physically, cognitively, and emotionally during the work. Engagement can be divided into two elements: personal engagement and personal disengagement. Personal engagement is the use of each member in the organization towards their role in the form of full attachment to the organization. Meanwhile, personal disengagement is the absence of a liaison from members of the organization to their own organization.

\subsection{Turnover Intention}

[12] argued that turnover intention is the tendency or intention of employees to quit their job voluntarily according to their own choice. Turnover is usually one of the last options for an employee, if he or she finds that the working conditions are no longer as expected. Robbins in [12] defined turnover as a permanent employee dismissal from the company, either by the employee himself (voluntarily) or by the company. Meanwhile, Low et. al., in [13] stated that turnover intention is the degree of attitude tendency of employees to look for new jobs in other places or they have plans to leave the company within a predetermined period.

\subsection{Conceptual Framework and Hypothesis}

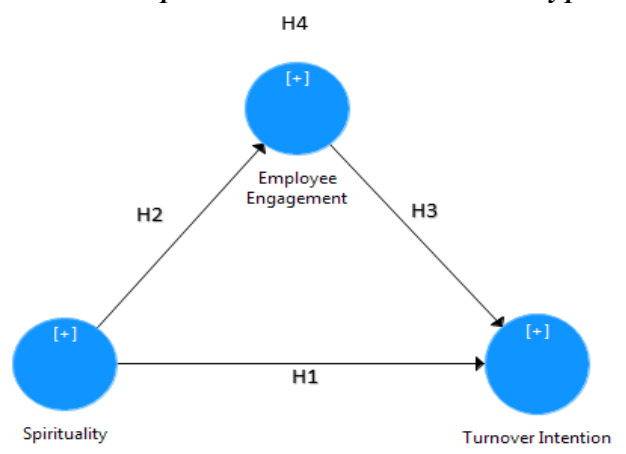

Figure 1 Conceptual Framework

Spirituality in the workplace will stimulate the employees to form a more positive perception of the organization and thus, will get better change and achieve better adjustment through their work with higher satisfaction, commitment to the organization, organizational welfare, and lower desire to do a turnover.

$\mathrm{H}_{1}$ : Spirituality has an effect on Turnover Intention.

Employee engagement is something that can affect employee performance. Therefore, if employees have an attachment to their work, it will be easier for the company to realize its vision. Meanwhile, spirituality realizes that human beings have an inner life that grows and is cultivated by meaningful work that takes place in a community context.

$\mathrm{H}_{2}$ : Spirituality has an effect on Employee Engagement. Companies can enhance the performance of their employees through increasing the employee engagement. Employees having strong ties with the company will enhance their work performance for the company's benefit [19]. A similar sentiment was also expressed by [20] stating that employee engagement can result the success for companies through enhancing the employee performance.

$\mathrm{H}_{3}$ : Employee Engagement has an effect on Turnover Intention.

$\mathrm{H}_{4}$ : Spirituality has an effect on Turnover Intention mediated by Employee Engagement. 


\section{RESEARCH METHOD}

This research aimed to examine whether there is an effect of spirituality on turnover intention mediated by employee engagement among the WOM Finance employees. In service sector, especially in financial industry, the role of people is very important. The population in this research was 460 volunteers working in WOM Finance Head Office. Slovin formula was used as the sampling technique, and the results obtained 214 people.

In examining the Spirituality, a questionnaire was developed by [9]. Employee engagement was measured by using the item of [10]. Turnover intention was examined by using a questionnaire developed by Chen and Francesco in [14]. This research data was processed by using PLS-SEM software through two measurements: Outer model (Measurement model) and Inner model (Structural model). 1. Outer model was used to examine the relationship between latent variables and their indicators; i.e., to explain how each indicator is related to the latent variables. The inner model was used to examine how strong the estimation between latent variables was.

2. Convergent validity was used in this research to examine the correlation between the indicators and variable scores through the outer-loading value. According to [15], an outer-loading value at the threshold of 0.5 to 0.6 is considered to be valid.

3. Reliability was examined in reference to Cronbach's Alpha Coefficient score along with Composite Reliability with acceptable values $>0.70$ [15].

\section{ANALYSIS AND DISCUSSION}

\subsection{Measurement Model Test (Outer Model)}

The measurement model is used to test the accuracy of the relationships among the indicators in a variable in order to measure the latent variables. The test of measurement model consists of convergent validity test, discriminant validity test, and composite reliability test.

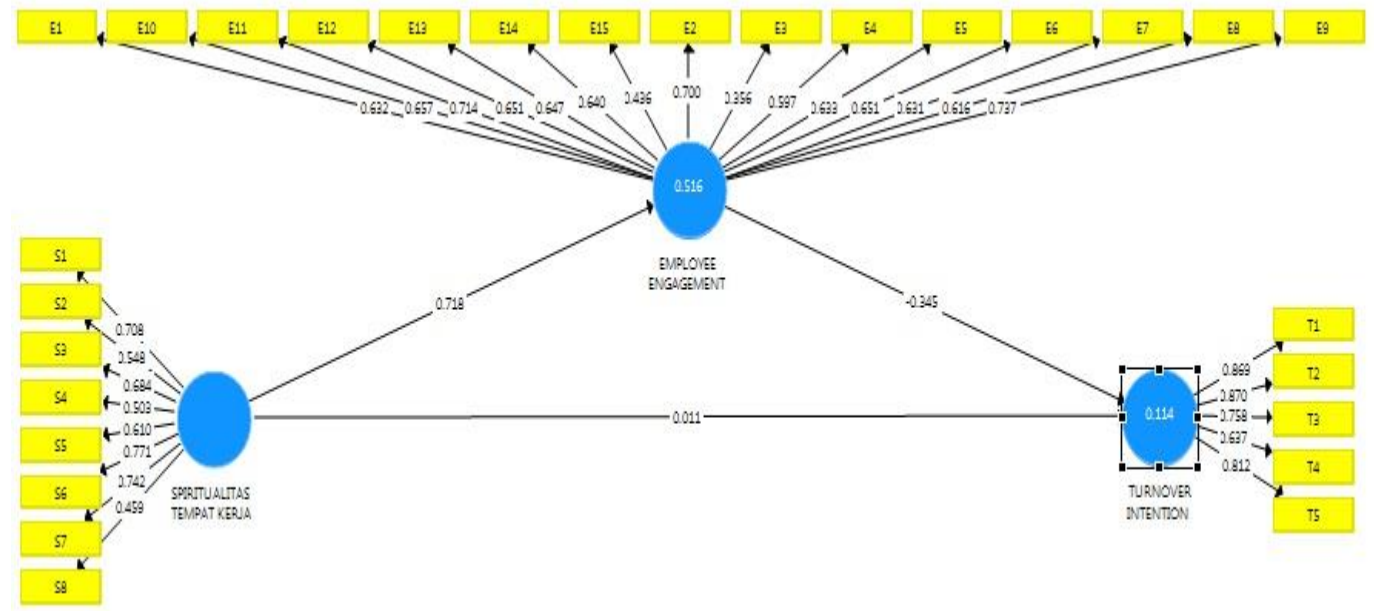

Figure 2 Loading Factor of Indicators

\subsection{Validity Test}

The validity test aims to measure the accuracy of the indicators in measuring the latent variables. According to [15], an indicator is valid, if it has a loading factor higher than 0.70 . In this study, all loading factors of the indicators were higher than 0.7 . Thus, all indicators were considered valid.

\subsection{Reliability Test}

A variable's reliability is measured based on the value of Cronbach's Alpha and the composite reliability that have to be greater than 0.7 [16].
Table 2 Composite Reliability Value

\begin{tabular}{|c|c|c|}
\hline & $\begin{array}{c}\text { Cronbach's } \\
\text { Alpha }\end{array}$ & $\begin{array}{c}\text { Composite } \\
\text { Reliability }\end{array}$ \\
\hline $\mathrm{E}$ & 0.862 & 0.893 \\
\hline $\mathrm{S}$ & 0.798 & 0.861 \\
\hline $\mathrm{T}$ & 0.827 & 0.851 \\
\hline
\end{tabular}

All variables in this study had the composite reliability and Cronbach's Alpha greater than 0.7. Thus, all variables in this study were considered reliable. 


\author{
4.4. Structural Model Test (Inner Model) - \\ Hypothesis Test
}

The structural model (inner model) in this study consists of one exogenous latent variable (Spirituality) and two endogenous latent variables (Employee Engagement and Turnover Intention).

Table 3 Path Coefficients

\begin{tabular}{|l|c|c|c|c|c|}
\hline & $\begin{array}{c}\text { Original } \\
\text { Sample (O) }\end{array}$ & $\begin{array}{c}\text { Sample Mean } \\
(\mathrm{M})\end{array}$ & $\begin{array}{c}\text { Standard } \\
\text { Deviation } \\
(\text { STDEV) }\end{array}$ & $\begin{array}{c}\text { t-Statistics } \\
(|\mathrm{O} / \mathrm{STDEV}|)\end{array}$ & $\mathrm{p}$-Values \\
\hline Spirituality $\rightarrow$ Turnover Intention & -0.122 & -0.131 & 0.135 & 0.900 & 0.368 \\
\hline Spirituality $\rightarrow$ Employee Engagement & 0.699 & 0.701 & 0.040 & 17.368 & 0.000 \\
\hline Employee Engagement $\rightarrow$ Turnover Intention & -0.173 & -0.180 & 0.136 & 1.274 & 0.203 \\
\hline
\end{tabular}

Source: Data Analysis Using PLS-SEM software

Table 4 Total Indirect Effect

\begin{tabular}{|l|c|c|c|c|c|}
\hline & $\begin{array}{c}\text { Original } \\
\text { Sample (O) }\end{array}$ & $\begin{array}{c}\text { Sample Mean } \\
\text { (M) }\end{array}$ & $\begin{array}{c}\text { Standard } \\
\text { Deviation } \\
\text { (STDEV) }\end{array}$ & $\begin{array}{c}\text { t-Statistics } \\
(\mid \mathrm{O} / \text { STDEV|) }\end{array}$ & p-Values \\
\hline $\begin{array}{l}\text { Spirituality } \rightarrow \text { Employee } \\
\text { Engagement } \rightarrow \text { Turnover } \\
\text { Intention }\end{array}$ & -0.121 & -0.126 & 0.096 & 1.260 & 0.208 \\
\hline
\end{tabular}

Source: Data Analysis Using PLS-SEM software

\section{$H_{1}$ : Spirituality has an effect on Turnover Intention.}

Spirituality will have an impact on feeling comfortable at work, and employees can work without coercion, because it is a form of worship in life. This feeling of comfort gives employees high spirituality, so the company engages them. Thus, the higher the spiritual life of employees, the higher the employee engagement will be. This positive relationship between spirituality and turnover intention was not confirmed in this study with a p-value of 0.368 , which is greater than the 0.05 significance level. Thus, there is no sufficient evidence to state that spirituality has a significant and negative effect on turnover intention. Spirituality is not able to create turnover intention, because the WOM Company has a high reputation so that the turnover intention occurs with more prestige and incentives both in financial and non-financial terms received from the company. Thus, whether employees have a high spirituality or not, they will remain in the company and are reluctant to leave, because what is obtained from the company is sufficient. This study did not support the research of [17] stating that there is an influence of spirituality on turnover intention.

\section{$\mathrm{H}_{2}$ : Spirituality has an effect on Employee Engagement.} Spirituality is able to create employee engagement in this study, whereas the influence of spirituality on engagement is 0.699 with a p-value of 0.000 , which is less than the significance level of 0.05 . Thus, there is enough evidence to state that spirituality has a significant and positive effect on employee engagement. This finding is confirmed by the finding of the research by [18], who stated that work spirituality has a positive effect on job satisfaction. The spirituality of work also has a positive effect on organizational attachment. Job satisfaction has a direct and positive effect on employee engagement.

\section{$\mathrm{H}_{3}$ : Employee Engagement has an effect on Turnover Intention.}

Not as expected, in this study there is no enough evidence to state that the employee engagement has an effect on turnover intention. Employees, who have a high attachment to the company, should feel at home working in that place, so they are reluctant to leave. However, in this study, turnover intention has no effect on employee engagement. Whether the employee has a sense of attachment to the company or not, the impact on turnover intention is nonexistent.

Employee engagement has no influence on turnover intention, whereas the value of t-statistics of 1.274 was smaller than the t-table of 1.96 , and the p-value equals to 0.203 , which was greater than 0.05 .

The result of this study did not support the research result from [13], who concluded that employee engagement has an influence on job satisfaction, and job satisfaction has an influence on turnover intention. Therefore, the higher the level of employee engagement is, the lower the tendency to change jobs will be (turnover intention is low).

Job involvement is the level in which a person relates him/herself to the job, actively participates in it, and considers that his/her performance is important to his/her self-worth [6]. Employee engagement is a participatory process that uses all the capacities of employees and is designed to encourage greater commitment to the success of the company. Employee engagement makes them feel 
valued, feel possessive, feel more responsible, feel prouder, and these will improve their performance.

\section{$H_{4}$ : Spirituality has an effect on Turnover Intention mediated by Employee Engagement.}

Employee engagement does not mediate the effect of spirituality on turnover intention. Spirituality has a direct effect on turnover intention, but the indirect effect of spirituality on turnover intention as mediated by engagement does not occur. This is because engagement is unable to create turnover intention, and there is a possibility that engagement is actually a moderation in the influence of spirituality on turnover intention (not mediation) so that the influence of spirituality on turnover intention will be more closely related to the presence of engagement. However, engagement does not become an intermediary or mediator in the influence of spirituality on turnover intention.

Employee engagement does not mediate the effect of spirituality against turnover intention, because the value of t-statistics of 1.260 is smaller than t-table of 1.96 and the pvalue of 0.208 is greater than 0.05 . The result of this study is also not supported by the research by [17] stating that spirituality has a direct effect on organizational commitment, and organizational commitment has a negative effect on turnover intention. This means that the higher organizational commitment is, the lower the turnover intention will be. Spirituality has a negative influence on turnover intention. This means that the higher spirituality is, the lower the turnover intention will be.

\section{CONCLUSIONS AND RECOMMENDATIONS}

\subsection{Conclusions}

Spirituality has an effect on employee engagement, but does not have an effect on turnover intention. In addition, employee engagement does not mediate the effect of spirituality on turnover intention. Therefore, the WOM Finance needs more enhanced employee engagement in order to retain their employees.

Other influential factors can also be analysed in further studies by adding more variables, such as job satisfaction, organizational commitment, work environment, and organization citizenship behaviour.

\subsection{Practical Recommendations}

a. Improving the functions of the Human Capital Division in conducting surveys on spirituality and employee engagement as a whole to the employees to find out the meaning or the working purpose of the employees and their expectations from the company, in relation to reducing the employee's turnover intention.

b. Improving the aspects of employee engagement in the company so that the employees may feel more engaged with the company. The company may provide activities that involve the employees directly in giving opinions, periodic employee competency improvement programs, and a comfortable and conducive working environment in providing infrastructure and workrelated culture.

\subsection{Theoretical Recommendations}

a. Future studies can use other variables, such as organizational commitment, job satisfaction, leadership style, or organizational culture to minimize the employee turnover intention.

b. Future research can be carried out in different business sectors, with the aim of complementing previous research, and can be used for more comprehensive decision making.

\section{REFERENCES}

[1] Fiermonte, Robert V., dan Bruning, Kelly. 2005. "The Value of Human Capital: Supporting Empowerment Strategies," Proceedings of the Academy of Organizational Culture, Communications and Conflict, 10(1), pp. 29-36.

[2] Nurofia, Fifie. 2009. "Getting to know Employee Management," Maranatha Journal of Psychology, vol. 6 (1), pp. $1-16$

[3] Robert, D.R., dan Davenport, T.O. 2002. "Job engagement: Why it's Important and How to Improve it," Employment Relations Today, 29 (3), pp. 21-36.

[4] Kreitner, Robert., dan Kinicki, Angelo Kinicki. 2010. Organizational Behavior. 9th Edition. New York, N.Y: McGraw-Hill/Irwin

[5] Mc Ewen, W. 2003. "Analysis of spirituality Contenst In Nursing Textbooks," Journal of Nursing Education, 43(1), pp. 20-30.

[6] Robbins, Stephen P., dan Judge, Timothy A. 2015. Organizational Behavior. $15^{\text {th }}$ Edition. Jakarta: Salemba Empat.

[7] Maslow, A.H., Stephens, D. C., \& Heil, G. 1998. Maslow on Management. Singapore: John Wiley \& Sons, Inc.

[8] Hill, P. C., Pargament, K. I., Hood, R. W., Jr., McCullough, M. E., Swyers, J. P., Larson, D. B., dan Zinnbauer, B. J. 2000. “Conceptualizing religion and spirituality: Points of Commonality, Points of Departure," Journal For The Theory Of Social Behaviour, 30, 51-77. 
[9] Ashmos, D. P., dan Duchon, D. 2000. "Spirituality at Work: A Conceptualization and Measure," Journal of Management Inquiry, 9 (2), pp. 134-145.

[10] Schaufeli, W.B., Salanova, M., Gonzalez-Roma, V., dan Bakker, A.A. 2002. "The Measurement of Engagement and Burnout: A Two-Sample Confirmatory Factor Analytic Approach," Journal of Happiness Studies, 3, pp. 71-92.

[11] Kahn, W. A. 1990. Psychological Conditions of Personal Engagement and Disengagement at Work," Academy of Management Journal, 33(4), pp. 692-724.

[12] Petrolina, T.A., Tjendra, Vennylia and Hartiningsih, Lina. 2009. "The Influence of Organizational Commitment, Role Conflict on Turnover Intention with Job Satisfaction," Journal of Accountability, Vol 8 (2), pp. 137-147.

[13] Rachman, Lutfi., dan Dewanto, Aryo. 2015. "The Effect of Employee Engagement on Job Satisfaction and Nurse Turnover Intention (Study at Wava Husada Hospital Kepanjen Malang)," Journal of Applied Management, 14 (2), pp. 322-333.

[14] Widodo, Rohadi. 2010. "Analysis of the Effect of Job Security and Organizational Commitment on Turnover Intention and the Impact on Outsourcing Employee Performance at PT. PLN Persero APJ Yogyakarta ". Semarang: Diponegoro University.

[15] Ghozali, Imam. 2014. Structural Equation Modeling Alternative method with Partial Least Squares (PLS). Fourth Edition. Semarang: Diponegoro University Publishing Agency.

[16] Hair, J.F., Black, W.C., Babin, B.J., \& Anderson, R.E. (2010). Multivariate Data Analysis. Seventh Edition. New Jersey: Prentice Hall.

[17] Budiono, Sugeng., Noermijati., dan Alamsyah, Arief. 2014. "The Influence of Spirituality on Turnover Intention of Nurses through Organizational Commitment at Islamic Hospital Unisma Malang,' Journal of Applied Management, 12(4), pp. 639-649.

[18] Janah, Nur., Sukmawati, Anggraini., dan Afendi, Farit Mochamad. 2017. "The Influence of Work Spirituality on Employee Attachment through Job Satisfaction in Bogor City SMEs", Journal of Management and Organization, 8(2), pp. 133-143.

[19] Lewiuci, Princes Grace., dan Mustamu, Ronny H. 2016. "Pengaruh Employee Engagement Terhadap Kinerja Karyawan Pada Perusahaan Keluarga Produsen
Senapan Angin,” Agora, Jurnal Mahasiswa Manajemen Bisnis, 4(2), pp. 101-107.

[20] Siddhanta, A., dan Roy, D. 2010. "Employee Engagement Engaging The 21st Century Workforce," Asian Journal of Management Research, ISSN: 22293795. 